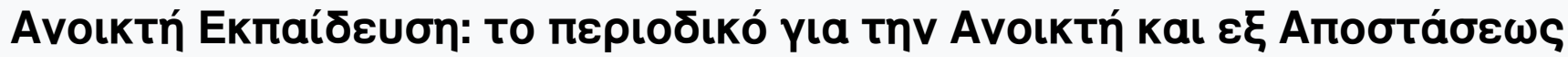

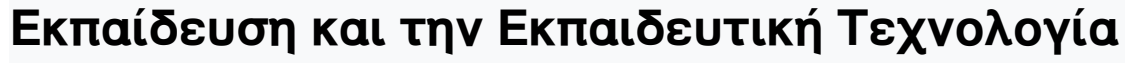

Tóн. 14, Ap. 1 (2018)

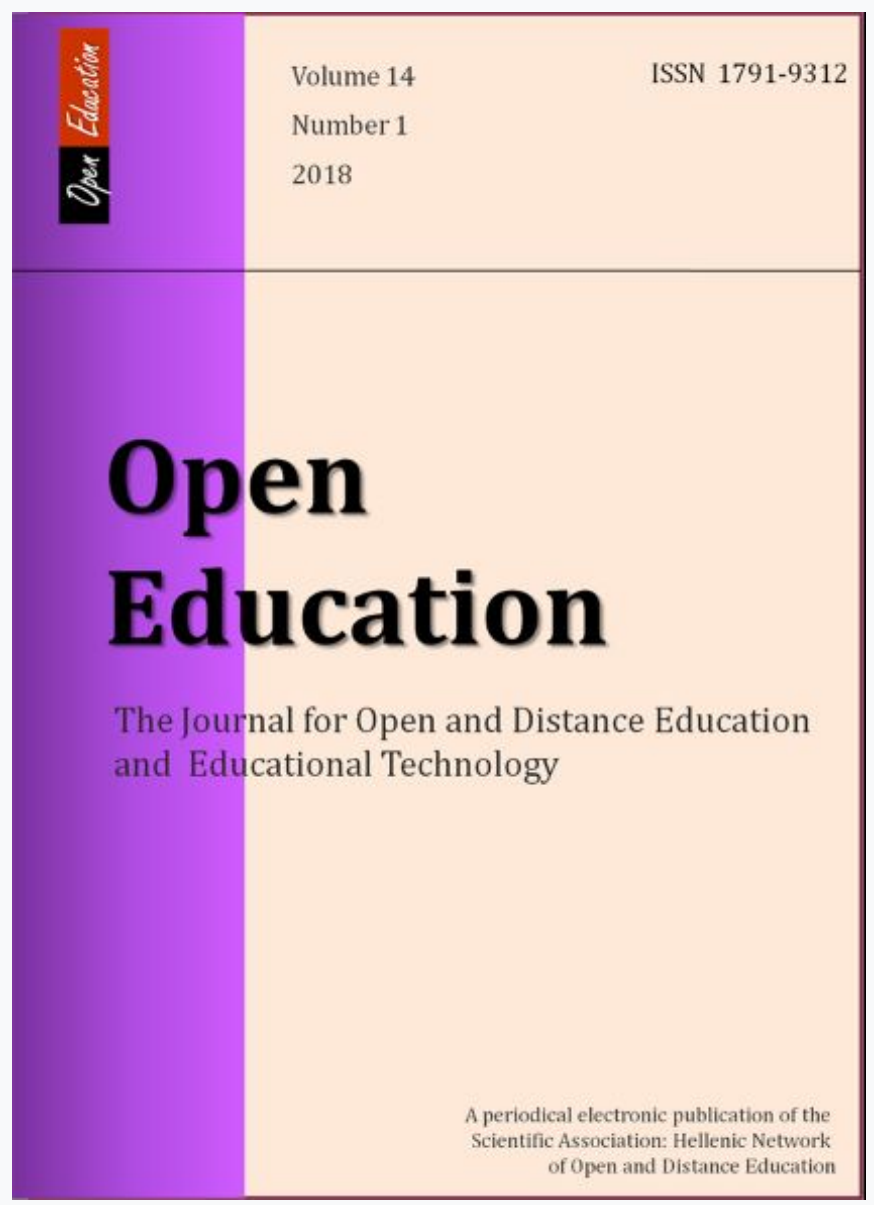

Development of a Learner Autonomy Scale

Smaragda Sereti, Yiannis Panteleimon Giossos

doi: $\underline{10.12681 / \text { jode. } 18212}$

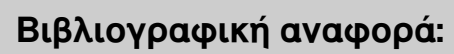




\section{Development of a Learner Autonomy Scale}

Smaragda Sereti

Open University of Cyprus smaragda_99@yahoo.com

Yiannis Giossos

University of Athens

xayiannis@gmail.com

\section{Summary}

In distance learning educational context, learner autonomy is an element of research since the decade of 1970. Consequently, there are a lot of theoretical and empirical research of learner autonomy in distance learning trying either to conceptualizing it or to measure it. There are at least eight scales for measuring learner autonomy but all of them have been developed in a different socio-educational context and although it is not a mistake to be used in different socio-educational context it is more appropriate to develop a new one for the specific context. Therefore the aim of this study was to develop a learner autonomy scale that can be used in the context of the Open University of Cyprus and provide psychometric evidence of reliability and validity of the interpretation of the scores derived from the scale. First, the concept of learner autonomy was clarified through literature review. Second information on students' beliefs and feelings about their learner autonomy was gathered. On the basis of the afore-mentioned procedures, an item pool was developed and was given to fourteen (14) university expertise of distance learning in order to evaluate the items and ensure content validity. Reliability and validity were then tested using exploratory factor analysis with a sample of two hundred and fiftyeight (258) undergraduate and postgraduate students from the Open University of Cyprus. Principal component analysis with oblimin rotation was used to determine the sufficient number of factors. The extraction of the number of factors was based on a) the theory; b) the scree plot test; c) eigenvalue-greater-than-one rule; d) the percentage of explained variance of each factor; e) the percentage of total explained variance and f) the number of factors that can be conceptually interpreted. Four dimensions of learner autonomy, namely, a) special ability to self-management, b) special psychological disposition, c) general ability to self-management and d) general psychological disposition, were revealed. The first factor explained $22.84 \%$ of the variance, the second factor $9.13 \%$ of the variance, the third factor $7.06 \%$ of the variance and the fourth factor $6.36 \%$ of the variance. Though some items in this scale were similar to those of other scales, factorial structure was different. Three different possible explanations proposed. The first was based on the differentiations of the educational environments the second on the fact that learner autonomy is a complex concept and therefore different conceptualizations of the term lead to different measurement scales and the third was based on the fact that all the scales measure perceived (form the student perspective) learner autonomy. Cronbach's alpha for the overall scale was .85 , for the factor of special ability to self-management 
was $.82, \mathrm{~b}$ ) for the factor of specific psychological disposition was .65 , c) for the factor of general self-management capacity was .76 and for the factor of general psychological disposition was .48. Finally, the Pillai's Trace showed no statistically significant gender differences in the four factors.

Key words: Autonomy, distance learning, distance education, scale development.

\section{Introduction}

In distance learning educational context, learner autonomy is an element of research since the decade of 1970 (Moore, 1972, 1973; Wedemeyer, 1977). At this point it is necessary to point out that etymologically the term autonomy is complex, consisting of the words "auto" and "nomos/law" and it means living under my own rules. The concept of autonomy has been used in many disciplines such as philosophy, politics, and medicine. The way in which different sciences have conceptually approached the term also reveals a variety of definitions. More specific the term learner autonomy means that the learner has the ability and the skill to decide what and how to learn something. He or she actively manages his/her learning, recognizes, evaluates his/her real learning needs, tries to shape his/her goals, plans the way and content of his/her learning process, controls and monitors his/her learning task and finally evaluates it (Brockett \& Hiemstra, 1991; Knowles, 1975; Little, 1994).

There are a lot of theoretical and empirical research of learner autonomy in distance learning (Chen, 2001a, 2001b; Guven \& Sunbul, 2007; Huang, 2002; Murphy, 2007; Saba \& Shearer, 1994; Vasiloudis, Koutsouba, Giossos \& Mavroidis, 2015; White, 1995), trying either to conceptualizing it or to measure it. The reason is simple and concerns the fact that distance learning is a form of education based on the principle of effective learning in which it is not necessary for the teacher and the learner to be in the same place (Gunawardena \& McIsaac, 2004) and therefore this separation creates a learning environment that imposes the learner's autonomy (Giagli, Giagli \& Koutsouba, 2010). Theoretical approaches to learner autonomy in distance learning are many (Anderson \& Dron, 2011; Garrison, 2000; Moore, 1993; Moore \& Kearsley, 1996; Zimmerman \& Schunk, 1989) and times they define it as ability and sometimes as a psychological state. In order to measure learner autonomy there is a need of a scale. Such scales are Guglielmino's Self-Directed Learning Readiness Scale (1977), Self-Directed Learning Readiness Scale for Nursing Education of Fisher, King, and Tague (2001), Learner Autonomy of Chen (2001a) which is a subscale of her Transactional Distance Scale, Distance Education Learning Environments (DELES) of Walker and Fraser (2005), Autonomy-Connectedness Scale (ACS-30) of Bekker and Van Assen (2006), Autonomous Learning Scale - AL of Macaskill and Taylor (2010) and Learner Autonomy Scale of Bei (2016). All the above scales have been developed in a different socioeducational context and although it is not a mistake to be used in different socioeducational context it is more appropriate to develop a new one for the specific context. In Cyprus economic and technological development imposed the need for continuous training and distance learning (Pavlakis \& Kaitelidou, 2007; Pavlakis \& Kaitelidou, 2012). In this context, the institute of the Open University of Cyprus in 2002 first legally regulated the application of open and distance education in higher education. The Open 
University of Cyprus has established a blended learning method for delivering their undergraduate and postgraduate programs. It uses face to face consulting meetings combined with online teleconferences. Particular students attend annual modules and participate on five counseling meetings with their teacher, one face to face and the rest online. The Open University of Cyprus designed their undergraduate and postgraduate programs following the same delivering teaching method of the Greek Open University but shortly after used a different method with online tools. Therefore a learner autonomy scale suitable for this educational context was needed. On this basis, the aim of this research was to develop a valid and reliable scale for learner autonomy of students on a blended learning context.

\section{Methodology}

In order to develop the learner autonomy scale, four phases had to be completed. At the beginning a literature review was contacted in order to clarify the learner autonomy concept and to detect and select suitable items from relative scales. Then information on Open University of Cyprus students' beliefs on how they understand the concept of learner autonomy was gathered. Subsequently on the aforementioned information and on the basis of the review of the existing scales of learner autonomy an item pool was created. Third, the scale was given to fourteen (14) university expertise of distance learning in order to be evaluated its content validity. Finally the structural validity and reliability of the scale was evaluated with the administration of the scale on a random sample of 258 undergraduate and postgraduate students of the university. Responses to items assessing the scale were analyzed using exploratory factor analysis (EFA). The sample number for each factorial analysis is considered sufficient because it exceeds ten times the number of queries on the scale (Kline, 2011). Principal component analysis with oblimin rotation was used to determine the sufficient number of factors (Fabrigar et al. 1999). The extraction of the number of factors was based on a) the theory; b) the scree plot test; c) eigenvalue-greater-than-one rule; d) the percentage of explained variance of each factor; e) the percentage of total explained variance and f) the number of factors that can be conceptually interpreted (Nunnally \& Bernstein, 1994). Reliability of the scale was determined using internal consistency among items, Multivariate analysis of variance was conducted to compare the mean scores of men and women on the autonomy scale.

\section{Creating an item pool}

In the field of education in general, Ho and Crookhall (1995) report that learner autonomy is firstly an attitude towards the learning process and secondly a skill, while Holec (1981: 3, cited by Benson \& Voller, 1997 : 1) defines it as the willingness and skill of a student to assume the responsibility of his or her studies. Finally, Benson \& Voller (1997: 2) points out that the term learner autonomy was used in at least five ways: a) situations in which learners study entirely on their own, b) a set of skills which can be learned and applied in self-directed learning, c) an inborn capacity which is suppressed by institutional education, d) the exercise of learner's responsibility for their own learning and e) the right of learners to determine the direction of their own learning. Summarizing all the definitions of learner autonomy it can be pointed out that it means ability or a disposition, or an attitude, or a mood or a skill that ensures that a student takes responsibility for his or her education. In the context of this research, learner autonomy 
defined the learner's ability to manage how and what he learns, but also the psychological disposition to take responsibility for the above. Since in distance education environments learning material and Information and Communication Technology are key factors (Matralis, 1998; Habibur, 2014) the learner's ability to manage them and the attitude towards them have been considered as key elements of learner autonomy.

Literature review revealed seven learner autonomy scales. The Self-Directed Learning Readiness Scale of Guglielmino (1977), Self-Directed Learning Readiness Scale for Nursing Education of Fisher, King and Tague (2001), the Transactional Distance scale of Chen (2001a) part of which concern autonomy, Distance Education Learning Environments Survey of Walker and Fraser (2005), Autonomy-Connectedness Scale (ACS-30) of Bekker and Van Assen (2006), Autonomous Learning Scale of Macaskill and Taylor (2010) and Learner Autonomy scale of Bei (2016). Four of them include appropriate items for this scale (Fisher, King \& Tague, 2001; Walker \& Fraser, 2005; Macaskill \& Taylor, 2010; Bei, 2016). In particular there were used items from a) Fisher, King and Tague scale (2001) dealing with time management and study environment, b) Walker and Fraser scale (2005) dealing psychological disposition, c) Macaskill \& Taylor, (2010) concerning psychological disposition as well as time management and d) Bei's scale (2016) concerning the student's ability to personally take responsibility for his / her learning path, to design his or her own steps. Finally, the item pool included forty questions.

\section{Content validity}

The above questionnaire was given to fourteen (14) university expertise of distance learning in order to evaluate content validity. According to the expertise' comments, eight items were corrected, four more items were added and fifteen were removed because they had the same meaning. Finally, there were 28 questions of the scale that were answered. The questions were formulated on a Likert scale ranging from 1 to 5 (1: Totally Disagree to 5: Absolutely Agree). Before examining the validity of the structure of the questionnaire, a pilot study was conducted with five students to examine whether the questions were understandable.

\section{Structure Validity}

Two hundred and fifty-eight (258) undergraduate and postgraduate students of the Open University of Cyprus took part in the fourth and final phase of the research which was about evaluating structural validity. All of them studied at the academic year 2017-2018. Of these, 192 completed the questionnaire electronically and the others in the field of the Group Advisory Meeting (OSA) by the researcher herself, who informed the students about the purposes of the research and assured them of their anonymous participation. Of these seventy-seven ( $1=77$ or $29.7 \%$ ) were men and one hundred and eighty-one (n2 = 181 or $69.9 \%$ ) women.

Initially, the factorability of the twenty eight items was examined. Kaiser-Meyer-Olkin measure of sampling adequacy was .827 , which is above the recommended value of 6 (Kaiser 1974) and Bartlett's test of sphericity was significant $\left(\chi^{2}(378)=2012,775, \mathrm{p}<\right.$ .000). Principal component analysis with oblimin rotation was used in order to determine the sufficient number of factors of the scale. Four factors were revealed above the Kaiser criterion 1 which combined explained $42.76 \%$ of the variance. One question showed low 
communality and a low loadings and was therefore removed. A second principal component analysis with oblique rotation was performed without the above mentioned item. The Kaiser-Meyer_Olkin of sampling adequacy was .827 and Bartlett's test of sphericity was significant $\left(\chi^{2}(351)=1942,549, \mathrm{p}<.000\right)$. Four factors were revealed above the Kaiser criterion 1 which combined explained $43.73 \%$ of the variance. And in this case there were problems in loadings. Specifically, another question has shown low communality and cross-loading. For this purpose this question was removed and a third analysis was made.

In the third principal component analysis with oblique rotation Kaiser-Meyer_Olkin of sampling adequacy was .825 and Bartlett's test of sphericity was significant $\left(\chi^{2}(325)=\right.$ $1889,371, \mathrm{p}<.000)$. Four factors revealed above the Kaiser criterion 1 combined explained $44.76 \%$ of the variance. In this analysis another item was removed because it was loaded in two factors (cross-loading). A fourth principal component analysis with oblique rotation was conducted. Kaiser-Meyer_Olkin of sampling adequacy was .825 and Bartlett's test of sphericity was significant $\left(\chi^{2}(300)=1779,273, \mathrm{p}<.000\right)$. Four factors revealed above Kaiser's criterion 1 combined explained $45.24 \%$ of the variance. And in the fourth analysis there were problems. In particular, another item was removed because it was loaded in two factors.

A fifth principal component analysis with oblique rotation was conducted. KaiserMeyer_Olkin of sampling adequacy was .819 and Bartlett's test of sphericity was significant $\left(\chi^{2}(276)=1617,266, \mathrm{p}<.000\right)$. Four factors revealed above the Kaiser criterion 1 combined explained $45.41 \%$ of the variance. None of the remaining questions posed a problem. The Scree plot (figure 1) was ambiguous and showed turning points that would justify 2 or 4 factors, but four were chosen. Table 1 shows the loadings and the communalities of the scale.

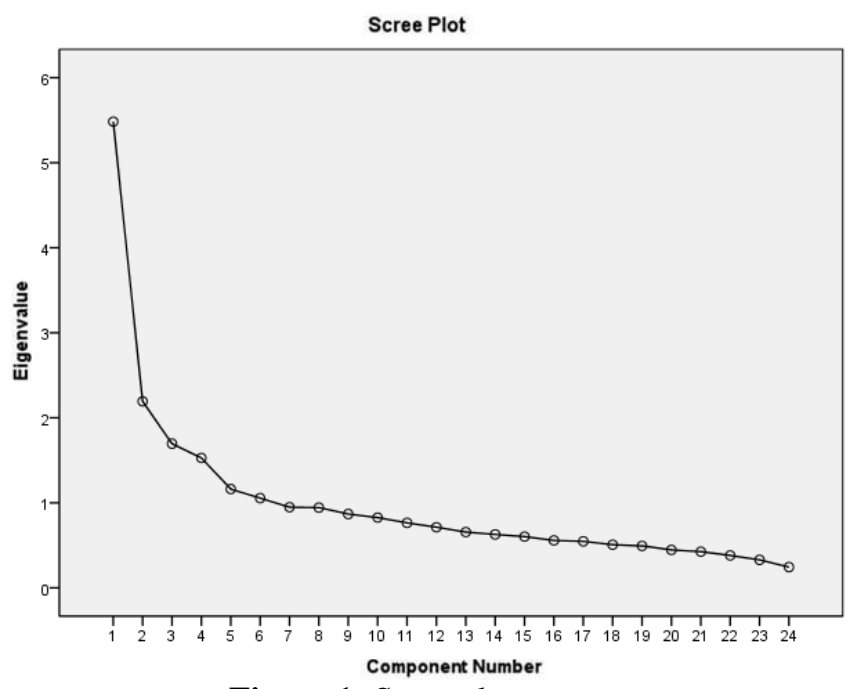

Figure 1: Scree plot 
Table 1: Loadings of items

\begin{tabular}{|c|c|c|c|c|}
\hline & \multicolumn{4}{|c|}{ Factors } \\
\hline & $\begin{array}{l}\text { Special } \\
\text { Ability to } \\
\text { Self- } \\
\text { Management }\end{array}$ & $\begin{array}{c}\text { Special } \\
\text { Psychologi } \\
\text { cal } \\
\text { Disposition }\end{array}$ & $\begin{array}{c}\text { General } \\
\text { Ability } \\
\text { to Self- } \\
\text { Manage } \\
\text { ment }\end{array}$ & $\begin{array}{c}\text { General } \\
\text { Psychol } \\
\text { ogical } \\
\text { Dispositi } \\
\text { on }\end{array}$ \\
\hline 19.I set specific targets &, 724 & & & \\
\hline $\begin{array}{l}\text { 17. I customize my schedule according to } \\
\text { my various obligations }\end{array}$ & ,719 & & & \\
\hline 20. I find alternatives to problems & 689, & & & \\
\hline 22. I choose the space that I will study & 686 & & & \\
\hline 23. I evaluate the course of my learning & ,622 & & & \\
\hline 18. Decide easily what I will study & 619 & & & \\
\hline 24. I plan carefully every step in my study &, 596 & & & \\
\hline $\begin{array}{l}\text { 21. I am preparing my work at the specified } \\
\text { time }\end{array}$ & ,593 & & & \\
\hline 14. I do not easily adapt & & ,658 & & \\
\hline $\begin{array}{l}25 \text {. I do not handle the programs necessary } \\
\text { for my training on the computer }\end{array}$ & & ,656 & & \\
\hline $\begin{array}{l}\text { 26. I feel lonely by studying with a distance } \\
\text { learning system }\end{array}$ & & ,616 & & \\
\hline 16. I do not easily mobilize myself & &, 585 & & \\
\hline $\begin{array}{l}\text { 12. I do not feel very happy when I work } \\
\text { alone }\end{array}$ & &, 538 & & \\
\hline 28. I cannot work with my fellow students. & & ,498 & & \\
\hline 2. I make my own decisions & & & ,759 & \\
\hline $\begin{array}{l}\text { 1. I personally take responsibility for my } \\
\text { learning course }\end{array}$ & & & ,758 & \\
\hline 3. I can also evaluate my cognitive abilities & & &, 730 & \\
\hline 5. I solve my problems & & & ,621 & \\
\hline 6. I acknowledge my shortcomings & & &, 592 & \\
\hline $\begin{array}{l}\text { 7. I can also find educational material for } \\
\text { my education }\end{array}$ & & & ,564 & \\
\hline $\begin{array}{l}\text { 13. I manage my own technical issues of } \\
\text { my education (eg PC and software) }\end{array}$ & & & ,437 & \\
\hline 4. I do not feel pressure & & & & ,686 \\
\hline $\begin{array}{l}\text { 27. I am under pressure from family and } \\
\text { other obligations }\end{array}$ & & & & ,652 \\
\hline $\begin{array}{l}\text { 10. I reward myself for every success } \\
\text { having previously chosen the rewarding } \\
\text { mode }\end{array}$ & & & &, 532 \\
\hline$\%$ variance & 22,84 & 9,13 & 7,06 & 6,36 \\
\hline
\end{tabular}




\begin{tabular}{ccccc}
\hline & \multicolumn{4}{c}{ Factors } \\
& & General & General \\
& Special & Special & Ability & Psychol \\
Ability to & Psychologi & to Self- & ogical \\
& Self- & cal & Manage & Dispositi \\
Management & Disposition & ment & on \\
\hline
\end{tabular}

19.I set specific targets

17. I customize my schedule according to my various obligations

20. I find alternatives to problems

22 . I choose the space that I will study

23. I evaluate the course of my learning

18. Decide easily what I will study

24. I plan carefully every step in my study

21. I am preparing my work at the specified time

14. I do not easily adapt

25. I do not handle the programs necessary for my training on the computer

26. I feel lonely by studying with a distance learning system

16. I do not easily mobilize myself

12. I do not feel very happy when I work alone

28. I cannot work with my fellow students.

2. I make my own decisions

1. I personally take responsibility for my learning course

3. I can also evaluate my cognitive abilities

5. I solve my problems

6. I acknowledge my shortcomings

7. I can also find educational material for my education

13. I manage my own technical issues of my education (eg PC and software)

4. I do not feel pressure

, 724

,719

,689

, 686

, 622

,619

, 596

, 593

27. I am under pressure from family and other obligations

10. I reward myself for every success

having previously chosen the rewarding

mode

$\%$ variance

22,84

9,13

7,06

6,36

, 658

,656

, 616

, 585

, 538

,498

,759

, 758

, 730

,621

, 592

,564

, 437

, 686

,652

Oblique rotation. 
The internal consistency of the sub-scale "Special Self-Management Ability" was highly reliable as Cronbach's $\alpha$ was a $=.82$. The internal consistency of the sub-scale "Special Psychological Disposition" had sufficient reliability as Cronbach's $\alpha$-index was $\alpha=.65$. The internal consistency of the sub-scale "General Self-Management Ability" was highly reliable as Cronbach's $\alpha$ was $\mathrm{a}=.76$. However, the internal consistency of the sub-scale "General Psychological Disposition" was low as the Cronbach $\alpha$ index was $\alpha=.48$. Finally, the Pillai's Trace showed no statistically significant gender differences in the four factors $\mathrm{V}=0.68, \mathrm{~F}(8,506)=2.218 \mathrm{p}>.05$.

\section{Discussion - Conclusions}

The aim of this study was to develop a valid and reliable scale for learner autonomy on the context of Open University of Cyprus. The results of the four phase's research revealed four factors. In particular: 1) general psychological disposition, 2) specific psychological disposition, 3) general self-management ability, and 4) specific selfmanagement ability. Though some items in this scale are similar to those of Macaskill \& Taylor (2010) and Bey (2016), factorial structure is different. In particular, the Macaskill \& Taylor scale (2010) concerned independence of learning and study habits, while Beis (2016) self-knowledge of autonomy, autonomy in dealing with difficulties, autonomy in planning and autonomy in practice. One possible explanation is based on the differentiations of the educational environments. Another reasonable explanation is the fact that learner autonomy is a complex concept and therefore different conceptualizations of the term lead to different measurement scales. A third plausible explanation is based on the fact that all the aforementioned scales measure perceived (form the student perspective) learner autonomy. In other words, those scales not only are composed form self-reported answers but also are developed from the student's perspective.

In the context of this research, learner autonomy was defined as the learner's ability to manage how and what he learns, as well as the psychological disposition to take responsibility for the above. Factor analysis results indicated that the scale produced valid scores for the learner's ability to manage how and what (general and specific selfmanagement ability) and valid scores for the learner's psychological disposition (general and specific psychological disposition). The assumptions of a research are premises without which the research could not proceed. The main assumption of this research was the participants' sincerity. The limitations of a research are choices that the researcher takes in order to make a research problem workable. The limitations of this research were the educational context and target population. In particular, the context of Open University of Cyprus and its undergraduate and postgraduate students.

\section{References}

Anderson, T., \& Dron, J. (2011). Three Generations of Distance Education Pedology. International Review of Research in Distance Learning, 12(3), 80-97.

Bei, E. (2016). Developing a range of autonomy for students in the HOU. Unpublished Postgraduate Thesis. Patras: HOU.

Bekker, M.H.J., \& Van Assen, M.A.L.M. (2006). A Short Form of the Autonomy Scale: Properties of the Autonomy - Connectedness Scale (ACS-30). Journal of personality assessment, 86(1), 51-60.

Benson, P. \& Voller, P. (1997). Autonomy and Independence in Language Learning. London: Longman. 
Brockett, R. G. \& Hiemstra, R. (1991). Self - Direction in Adult Learning: Perspectives on Theory, Research and practice. London and New York: Roudledge.

Chen, Y. J. (2001a). Transactional distance in Word Wide Web learning environments. Innovations in Education and Teaching International, 55(4), 327-338.

Chen, Y. J. (2001b). Dimensions of transactional distance in Word Wide Web learning environment: A factor analysis. British Journal of Educational Technology, 52(4), 459-470.

Fabrigar, L. R., D. T. Wegener, R. C. MacCallum, and E. J. Strahan. (1999). Evaluating the use of exploratory factor analysis in psychological research. Psychological Methods 4, 272-299, doi:10.1037/1082-989X.4.3.272

Fisher, M., King, J., \& Tague, G. (2001). Self-directed Learning Readiness Scale. Nurse Education Today, $21,516-525$.

Garrison, D. R. (2000). Theoretical challenges for distance education in the $21^{\text {st }}$ century: A shift from structural to transactional issues. International Review of Research in Open and Distance Learning, 1(1), (pp. 1-17). Available online at: http://www.irrodl.org/index.php/irrodl/article/view File/2/22

Giagli, S., Giaglis, G., \& Koutsouba, M. (2010). Autonomy in Learning in Distance Learning. Open Education Journal, 6(1\&2), (pp. 93-106).

Guglielmino, L. M. (1977). Development of the Self-directed Learning Readiness Scale. Unpublished doctoral dissertation, University of Georgia.

Gunawardena, C. N. \& Mclsaac, M. S. (2004). Distance Education. In D. H. Jonassen (Ed.), Handbook of Research on Educational Communications and Technology (2 $\left.{ }^{\text {nd }} e d\right)$ (pp. 355-395). London: Lawrence Erlbaum Associates Publishers.

Guven, Z., \& Sunbul, A. M. (2007). The Relation between the Learner's Autonomy Level and their Learning Styles. Paper presented in International Conference on Quality in Education in the Balkan Countries. Thessaloniki, Greece.

Habibur, R. (2014). The Role Of Ict In Open And Distance Education. Turkish Online Journal of Distance Education. 15(4), 162-169. Available online at: https://files.eric.ed.gov/fulltext/EJ1044189.pdf

Ho, J. \& Crookhall, D. (1995). Breacking with Chinese cultural traditions: learner autonomy in English Language teaching, System, 23(2), 235-243.

Holec, H. (1981). Autonomy in Foreign Language Learning. Oxford: OUP.

Huang, H. M. (2002). Student perceptions in an $\mathrm{n}$ online mediated environment. International Journal of Instructional Media, 29(4), 405-422.

Kline, R. (2011). Principles and Practice of Structural Equation Modeling. New York: Guilford.

Knowles, M. S. (1975). Self - Directed Learning: A Guide for Learners and Teachers .New York: Association Press.

Little, D. (1994). Learner Autonomy: a theoretical construct and is practical applications. Die Neueren Sprachen,93(5), 430-442.

Macaskill, A. \& Taylor, E. (2010). The development of a brief measure of learner autonomy in university students. Studies in Higher Education, 35(3), 351-359.

Matralis, C. (1998). The printed material in distance education. In: A. Kokkos, X. Lionarakis, C. Matralis, \& Ch. Panagiotakopoulos. Open and Distance Learning Educational material and new technologies. (Vol. 3, pp. 21-49). Patras: HOU

Moore, M. G . \& Kearsley, G. (1996). Distance Education: A systems view. New York: Wadsworth.

Moore, M. G. (1972). Learner autonomy: the second dimension of independent learning. Convergence 5(2), 76-88.

Moore, M. G. (1973). Toward a Theory of independent Learning and Teaching. Journal of Higher Education. 44(12), 661-679.

Moore, M. G. (1993). Theory of transactional distance. In D. Keegan (Ed.), Theoretical principles of distance education. (pp. 22-38). New York: Routledge.

Murphy, L. (2007). Supporting learner autonomy: theory and practice in a distance learning context. In D. Gardner (Ed.), Learner Autonomy 10: Integration and Support. Authentic books for language teachers, 10, (pp.72-92). Dublin, Ireland: Authentic Language Learning Resources Ltd.

Nunnally, J. C., \& Bernstein, I. C. H. (1994). Psychometric theory. (3rd ed). New York: McGraw-Hill.

Pavlakis, A., \& Kaitelidou, D. (2007). Open and Distance Education and Cyprus Reality From idea to Materialization. In A. Lionarakis (editor). Proceedings of 4th International Conference in Open and Distance Learning "Forms of Democracy on Education: Open Access and Distance Education". (Vol. B, 582-592). 
Pavlakis, A., \& Kaitelidou, D. (2012). Burnout syndrome in students of distance learning program: The Open University of Cyprus Experience. European Journal of Open, Distance and E-Learning, 15(1). Available online at: $\mathrm{http}: / / \mathrm{www}$.eurodl.org/materials/contrib/2012/Pavlakis_Kaitelidou.pdf

Saba, F., \& Shearer, R. (1994). Verifying key theoretical concepts in a dynamic model of distance education. The American Journal of Distance Education 9(1), 36-59.

Vasiloudis, G., Koutsouba, M., Giossos, Y., \& Mavroidis, I. (2015). Transactional distance and autonomy in a distance learning environment. European Journal of Open, Distance and e-Learning,18(1), 1141220.

Available

online

at: http://www.eurodl.org/index.php? $\mathrm{p}=$ archives $\&$ year $=2015 \&$ halfyear $=1 \&$ article $=687$

Walker, S. L., \& Fraser, B. J. (2005). Development and Validation of an Instrument for Assessing Distance Education Learning Environments in Higher Education: The distance Education Learning Environments Survey (DELES). Learning Environments Research 8(3), 289-308, doi:10.1007/s10984-005-1568-3.

Wedemeyer, C. A. (1977). Independent study. In A.S. Knowles (ed.), The International Encyclopedia of Higher Education. (Vol 5), 2114-2132. Boston: CIHED.

White, C. (1995). Autonomy and Strategy use in distance foreign language learning: research findings. System, 23(2), 207-221.

Zimmerman, B. J. \& Schunk, D. H. (1989). Self-regulated learning and academic achievement: Theory, research, and practice. New York: Springer-Verlag. 